\title{
Miocene Larger Benthic Foraminifera from the Kalumpang Formation in Tawau, Sabah
}

(Foraminifera Bentos Besar Berusia Miosen dari Formasi Kalumpang di Tawau, Sabah)

\author{
JUNAIDI ASIS* \& BASIR JASIN
}

\begin{abstract}
Miocene larger benthic foraminifera have been discovered from a limestone unit of the Kalumpang Formation. The limestone is exposed at the Teck Guan Quarry, Tawau, southeast Sabah. The Kalumpang Formation consists predominantly of interbedded mudstone and sandstone (graywacke), conglomerate, limestone, marl, chert and volcanic rocks. Five limestone samples have been collected and processed for petrographic analysis and identification of larger benthic foraminifera. The limestone is classified as packstone and mudstone. A total of seventeen species of larger benthic foraminifera have been identified. The foraminifera are divided into two assemblages namely Assemblage I and Assemblage II. Assemblage I is characterized by the presence of Lepidocyclina (Nephrolepidina) parva, Operculina sp. and Lepidocyclina (Eulepidina) formosa. This assemblage is an indicative of Aquitanian to Burdigalian in age (Early Miocene). Assembalge II comprises of Lepidocyclina (Nephrolepidina) sumatrensis, Lepidocyclina (Nephrolepidina) angulosa, Lepidocyclina (Nephrolepidina) ferreroi Lepidocyclina $s p$., Miogypsina $s p$. , Katacycloclypeus annulatus, Katacyloclypeus martini, Cycloclypeus carpenteri, Cycloclypeus indopacificus, Cycloclypeus sp., Flosculinella bontangensis, Operculina complanata, Amphistegina bowdenensis and Amphistegina sp. This assemblage is an indicative of Langhian to Serravallian age (Middle Miocene). The foraminiferal assemblages suggest that the depositional environment was a warm tropical shallow-marine at the fore-reef shelf zone.
\end{abstract}

Keywords: Kalumpang Formation; larger benthic foraminifera; Miocene; Tawau

\section{ABSTRAK}

Foraminifera bentos besar berusia Miosen telah ditemui daripada unit batu kapur Formasi Kalumpang. Batu kapur tersebut terdedah di Kuari Tech Guan, Tawau, tenggara Sabah. Formasi Kalumpang ini terdiri daripada selang-lapis batu lumpur dan batu pasir (greiwak), konglomerat, batu kapur, marmar, rijang dan batuan volkano. Lima sampel batu kapur telah diambil dan diproses untuk analisis petrografi dan pengenalpastian foraminifera bentos besar. Sebanyak tujuh belas spesies foraminifera bentos besar telah dikenal pasti. Foraminifera dibahagikan kepada dua himpunan iaitu Himpunan I dan Himpunan II. Himpunan I dicirikan oleh kehadiran Lepidocyclina (Nephrolepidina) parva, Operculina sp. dan Lepidocyclina (Eulepidina) formosa. Himpunan ini menunjukkan usia Aquitanian hingga Burdigalian (Miosen Awal). Himpunan II terdiri daripada Lepidocyclina (Nephrolepidina) sumatrensis, Lepidocyclina (Nephrolepidina) angulosa, Lepidocyclina (Nephrolepidina) ferreroi Lepidocyclina $s p$., Miogypsina sp., Katacycloclypeus annulatus, Katacyloclypeus martini, Cycloclypeus carpenteri, Cycloclypeus indopacificus, Cycloclypeus sp., Flosculinella bontangensis, Operculina complanata, Amphistegina bowdenensis dan Amphistegina sp. Himpunan ini menunjukkan usia Langhian hingga Serravallian (Miosen Tengah). Himpunan foraminifera ini membuktikan bahawa sekitaran pengendapannya adalah pada sekitaran laut cetek kawasan tropika di zon pelantar depan terumbu.

Kata kunci: Foraminifera bentos besar; Formasi Kalumpang; Miosen; Tawau

\section{INTRODUCTION}

The Kalumpang Formation was first introduced by Kirk (1962) and consists predominantly of interbedded mudstone and sandstone (graywacke), conglomerate, limestone, marl, chert and volcanic rocks. The formation is located at Upper Sungai Kalumpang, Binuang Valley, Sebatik Island and Semporna Peninsular, southeast Sabah. The formation is divided into 4 rock units namely Sebatik Sandstone-Shale Member, Sipit Limestone Member, Sandstone Chert Facies and Volcanic Facies (Kirk 1962). The Sipit Limestone Member forms four small isolated hills on the north coast of Semporna Peninsular. The limestone forms seven small N-S trending hills at km 50 from Tawau along the Kunak Road (Lim 1981).

Recently, we discovered well-preserved Miocene larger benthic foraminifera from the Sipit Limestone Member of the Kalumpang Formation. The outcrop is exposed at the Teck Guan Quarry along the Kunak-Tawau road. It overlies tuff and contains coral, algae, echinoids and foraminifera. This limestone is generally massive consisting of grey color and white spot of larger benthic foraminifera. The objective of this research was to identify 
larger benthic foraminiferal species and their significance in determination of age and depositional environments.

\section{GeOLOGICAL SETTING}

Kirk (1962) suggested that the age of the Kalumpang Formation range from Upper Oligocene to Upper Miocene and the age has been confirmed by Lee (1988). However, Lim (1981) reported that the age of the Kalumpang Formation is Early to Middle Miocene age. The formation is faulted and thrusted against the Darvel Bay Ophiolite Complex at the Darvel Bay area. The basal boundary of the Darvel Bay Ophiolite Complex and the Kalumpang Formation is not exposed. The Darvel Bay Ophiolite Complex (DBOC) is composed of ophiolitic rock association which represents remnant of supra-oceanic crust. The age of chert sediment was thought to be Cretaceous ranging from Barremian to Valanginian (Leong 1977) and later revised and assigned to a range from Aptian to Turonian in age (Junaidi \& Basir 2013, 2012, 2010). The age of igneous rock was older than chert perhaps Jurassic in age. The Kalumpang Formation is overlain by the UmasUmas Formation in the lower of the Umas-Umas Valley. The boundary between the Kalumpang Formation and Umas-Umas Formation was probably unconformable. The Kalumpang Formation is also overlain by Tertiary volcanic rock in the Mount Wullersdorf and the Mount Magdalena area. Then formation is covered by Quaternary sediments in the Balung Valley (Kirk 1962; Lee et al. 2004).

Lee et al. (2004) suggested the carbonaceous sediments of the Sebatik Sandstone-Shale Member and the limestone of the Sipit Limestone member were deposited in a geosynclinal environment. The Kalumpang Formation was deposited in a shelf environment. Hutchison (2005) stated depositional environment of the Kalumpang Formation was in transition to shallower water on the apron of the volcanic arc and it includes volcanic and pyroclastic material.

\section{OCCURRENCE OF LIMESTONE}

An extensive outcrop of bedded limestone was exposed at the Teck Guan Quarry site, approximately $50 \mathrm{~km}$ east of Tawau Town (Figure 1). The bedded limestone occurs as small hills with high cliff that represents karst topography. The thickness of exposed rock is about $46 \mathrm{~m}$. The rocks strike almost north-south direction and dip eastwards. The limestone is grey in colour and is overlain by green tuff.

\section{MATERIALS AND METHODS}

A total of five samples of carbonate rocks have been collected from the Teck Guan Quarry at the interval of $5 \mathrm{~m}$. The limestone samples have been cut into several thin sections. A total of fifty thin sections have been analyzed for carbonate rock classification and foraminiferal identification. Preparations of thin sections are based on standard micropaleontology method. The thin section examined by using polarized microscope for petrographic analysis and foraminiferal identification. The identification of larger benthic and other faunas is based on previous works (Adam 1970; BouDagher-Fadel 2008; Cole 1963; Ellis \& Messina 1965).

\section{RESULTS AND DISCUSSION}

\section{PETROGRAPHY OF CARBONATE ROCK}

Fifty thin section samples from five samples of carbonate rock have been cut for petrographic analysis. The classification of rock is based on Dunham (1962). Sample LKF1, LKF2, LKF3 and LKF4 are classified as wackstone (Figure 2(a), 2(b), 2(c)). All four samples are matrix supported and contain more than $10 \%$ of skeletal grains. Sample LKF5 is grains supported with low percentage of matrix. The grains comprise mainly larger foraminifera. This sample is classified as packstone. All the limestone

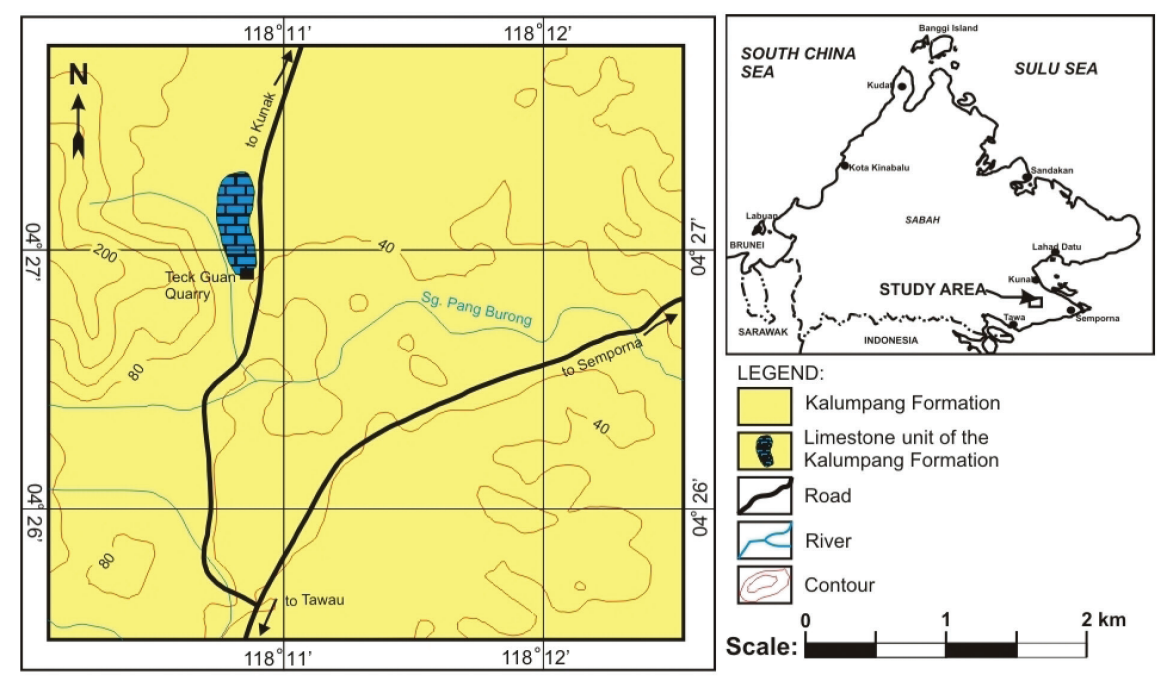

FIGURE 1. Geological Map of the study area and its locations 

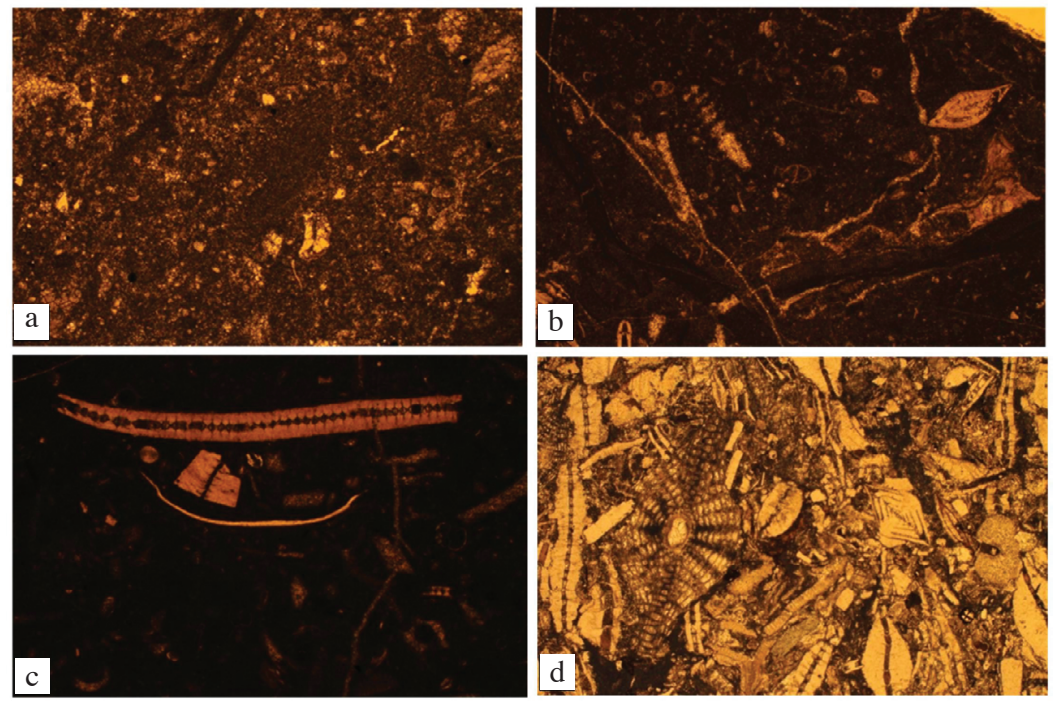

FIGURE 2. Photomicrographs of limestone (a) Sample LKF1-wackstone, (b) Sample LKF2-wackstone,

(c) Sample LKF3-wackstone and (d) Sample LKF5-packstone

samples contain skeletal allochems of algae, bivalves, foraminifera and corals.

\section{BIOSTRATIGRAPHY}

The limestone contains well-preserved fossils like larger benthic foraminifera, alga, coral and planktic foraminifera. The most abundance fossils are larger benthic foraminifera. A total of 17 species of larger benthic foraminifera have been indentified and listed in alphabetical order as follow:

Amphistegina bowdenensis Bermudez (Figure 5; 1-5)

Amphistegina sp. (Figure 5; 6-7)

Cycloclypeus carpenteri (Martin) (Figure 3; 9-11)

Cycloclypeus indopacificus Tan Sin Hok (Figure 3; 8)

Cycloclypeus sp. (Figure 3; 12-13)

Flosculinella bontangensis (Rutten) (Figure 5; 8)

Katacycloclypeus annulatus (Martin) (Figure 3; 1-6)

Katacyloclypeus martini (Van der Vlerk) (Figure 3; 7)

Lepidocyclina (Eulepidina) formosa Schlumberger (Figure $4 ; 1-2)$

Lepidocyclina (Nephrolepidina) angulosa Provale (Figure 4; 3-6)

Lepidocyclina (Nephrolepidina) ferreroi Provale (Figure $4 ; 7)$

Lepidocyclina (Nephrolepidina) parva Oppenoorth (Figure $4 ; 12-17)$

Lepidocyclina (Nephrolepidina) sumatrensis (Brady) (Figure 4; 8-11)

Lepidocyclina sp. (Figure 4; 18-19)

Miogypsina sp. (Figure 4; 20-21)

Operculina complanata (Defrance) (Figure 5; 9-11)

Operculina sp. (Figure 5; 12)
The photomicrographs of foraminifera are portrayed in Figures 3, 4 and 5. Larger benthic foraminifera species distribution is shown in Figure 6.

The 'Letter Stage' classification was first published by Van der Vlerk and Umbgrove (1927) based on larger benthic foraminifera from Indonesia area. This scheme has been successfully used for biostratigraphic scheme for the Southeast Asia region. BouDagher-Fadel (2008) has done some modification on this 'Letter Stage' classification based on research from larger foraminifera of Indonesian region. In this study we use the 'Letter Stage' classification revised by BouDagher-Fadel (2008) to establish the age of larger benthic foraminifera of the Kalumpang Formation (Figure 3). The larger benthic foraminifera are divided into two assemblages namely Assemblage I and Assemblage II based on the previous stratigraphic distribution chart of larger benthic foraminifera species range established by Adam (1970), BouDagher-Fadel (2008), Cole (1963) and Ellis and Messina (1965) (Figure 7).

\section{ASSEMBLAGE I}

The first assemblage was found in sample LKF1 (mudstone) and LKF2 (wackstone). This assemblage contains rare fauna of Lepidocyclina (Nephrolepidina) parva Oppenoorth, Operculina sp. and Lepidocyclina (Eulepidina) formosa Schlumberger. These two species of foraminifera indicate an age not younger than lower Tf1 or equivalent the top of Burdigalian. The first appearance of Lepidocyclina (Eulepidina) formosa Schlumberger is in Early Oligocene and became extinct at the top stage of Te5 'Letter Stage' (Ellis \& Messina 1965). This species has also been found in the Lower Miocene deposits (upper Te/Te5) of East Java (Sharaf et al. 2005). Adam (1970) stated that the age for Lepidocyclina (Nephrolepidina) parva is in Early Miocene or in Te5 of 'Letter Stage'. Cole (1957) reported that the age of Lepidocyclina (Nephrolepidina) parva from 


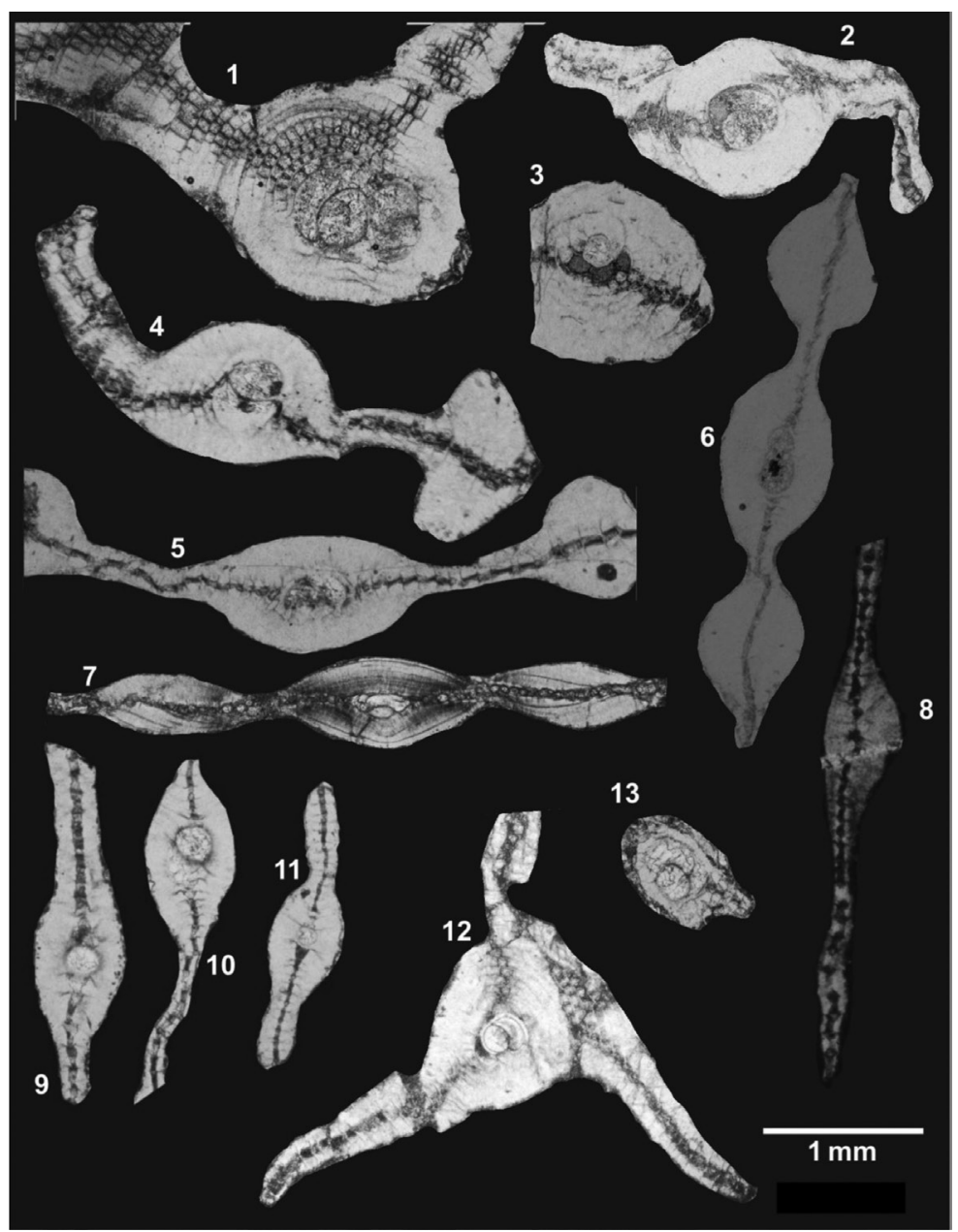

FIGURE 3. 1-3. Katacycloclypeus annulatus (Martin), equatorial section; 4-6. Katacycloclypeus annulatus (Martin), vertical section; 7. Katacycloclypeus martini (Van der Vlerk), vertical section; 8. Cycloclypeus indopaficus Tan Sin Hok, vertical section; 9-11. Cycloclypeus carpenteri (Martin), vertical section;

12. Cycloclypeus sp. equatorial section; 13. Cycloclypeus sp. half of vertical section

South Celebes is in upper Te 'stage' or Early Miocene. BouDagher-Fadel and Wilson (2000) found this species in Tf1, of Burdigalian to Langhian age from Southeast Kalimantan. In this study Lepidocyclina (Nephrolepidina) parva and Lepidocyclina (Eulepidina) Formosa are discovered in sample LKF2 of Te5 or Burdigalian in age. These two foraminifers' faunas indicate an age not younger than lower Tf1 or equivalent the top of Burdigalian (Early Miocene) (Figure 6).

\section{ASSEMBLAGE II}

The second assemblage was discovered from sample LKF3 and LKF4 of wackstone and sample LKF5 of packstone. The foraminifera consist of Lepidocyclina (Nephrolepidina) sumatrensis (Brady), Lepidocyclina (Nephrolepidina) angulosa Provale, Lepidocyclina (Nephrolepidina) ferreroi Provale, Miogypsina sp., Katacycloclypeus annulatus (Martin), Katacyloclypeus martini (Van der Vlerk), Cycloclypeus carpenteri (Martin), Cycloclypeus indopacificus Tan Sin Hok, Cycloclypeus sp., Flosculinella bontangensis (Rutten), Operculina complanata (Defrance), Amphistegina bowdenensis Bermudez and Amphistegina sp. Cycloclypeus and Katacycloclypeus are common in this assemblage. Katacycloclypeus annulatus Katacyloclypeus martini and Cycloclypeus indopacificus were dated as Serravallian of Tf2 by Cole (1963) from Tertiary deposits at Guam and Fiji. BouDagher-Fadel and Wilson (2000) reported this species in the lower Mid Miocene, Tf2 (early Serravallian) of Kalimantan. Similar faunas have also been recorded from Middle Miocene (Langhian to Serravalian) of Sulawesi, South Central Java and East Java Indonesia (BouDagher-Fadel 2002; BouDagherFadel \& Lokier 2005; Sharaf et al. 2005). Flosculinella bontangensis has been found in Serravalian deposits (Tf2) at South Central Java, Indonesia by BouDagherFadel and Lokier (2005). The presence of Lepidocyclina (Nephrolepidina) ferreroi, Katacycloclypeus annulatus, Katacyloclypeus martini, Cycloclypeus indopacificus and Flosculinella bontangensis indicated that the age is in Tf1/Tf2 or equivalent to Langhian to Serravallian (Middle Miocene) (Figure 6). 


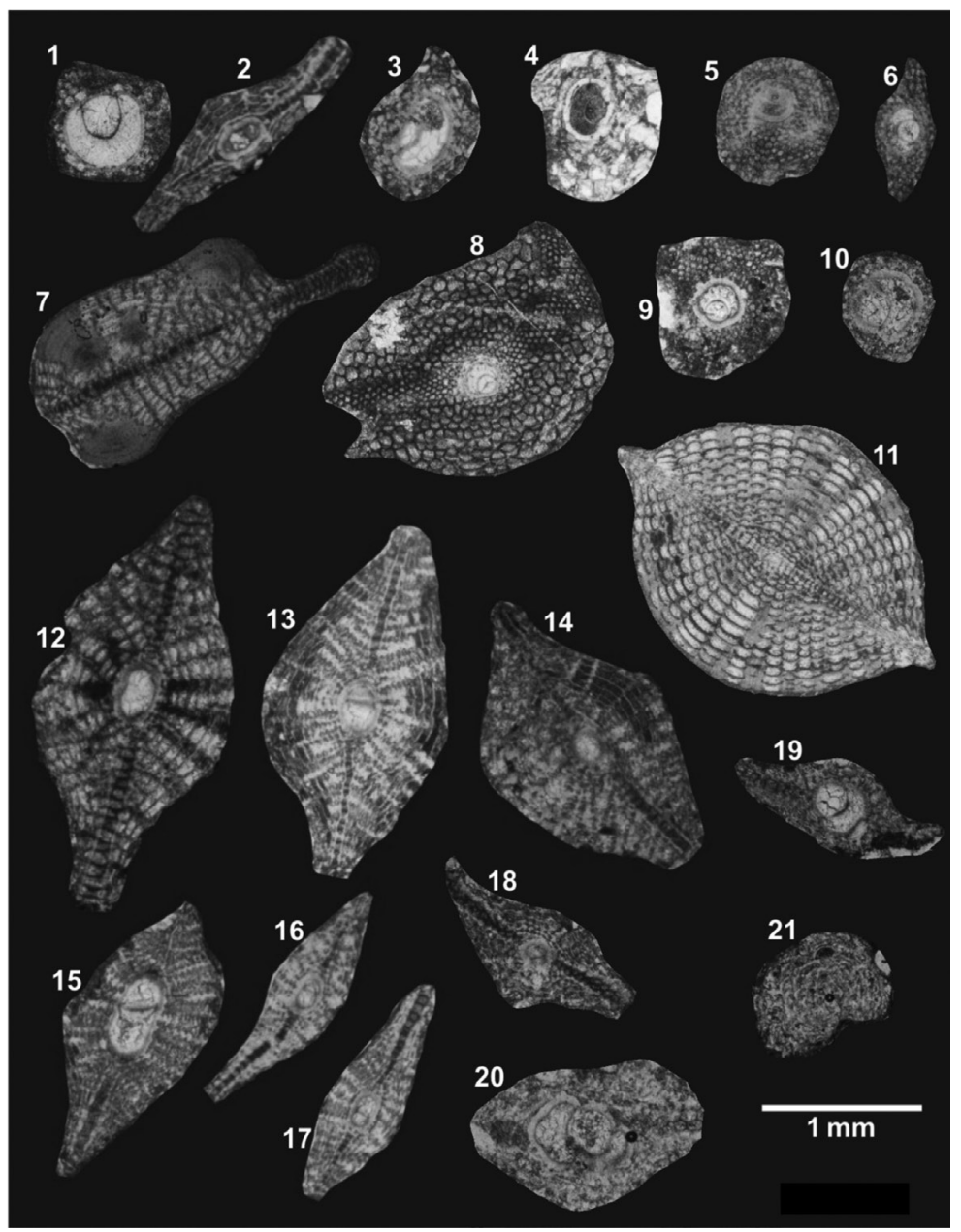

FIGURE 4. Lepidocyclina (Eulepidina) formosa Schlumberger, equatorial section; Lepidocyclina (Eulepidina) formosa Schlumberger, vertical section; 3-6. Lepidocyclina (Nephrolepidina) angulosa Provale, equatorial section; 7. Lepidocyclina (Nephrolepidina) ferreroi Provale, vertical section; 8-10. Lepidocyclina (Nephrolepidina) sumatrensis (Brady), equatorial section; 11. Lepidocyclina (Nephrolepidina) sumatrensis (Brady), vertical section; 12-17. Lepidocyclina (Nephrolepidina) parva

Oppenoorth vertical section; 18-19. Lepidocyclina sp. oblique equatorial section; 20-21. Miogyspina sp. equatorial section

\section{ENVIRONMENT OF DEPOSITION}

The carbonate rock in this study area was deposited in warm and very shallow-marine environment. The presence of well-preserved larger benthic foraminifera associated with coral and alga that found in limestone samples of the Kalumpang Formation indicate that the deposition occur within photic zone, that is less than $120 \mathrm{~m}$. BouDagherFadel (2008) divided a patch into three parts namely reef, fore-reef shelf and back-reef shelf. Fore-reef is the area that attacked by ocean swell and back-reef is the area where it sheltered from most of oceanic wave energies. The energy distribution produced characteristic carbonate lithofacies and allowed distinctive assemblages of foraminifera to flourish. In proximal fore-reef shelf, the most dominant foraminifera are cycloclypids, lepidocyclinids, operculinids, Amphistegina and Heterosteginids associated with scattered alga and coral and cemented by sparite and micrite (BouDagher-Fadel 2008) (Figure 8). This area represents the sample LKF5 of packstone which has high percentage grains of larger benthic foraminifera and it has low percentage of micrite because lime mud was flushed away by the wave action. The distal part of the forereef, was located below the wave base and the larger benthic foraminifera have been diminished and the mud became more dominant. This represented by samples LKF1, LKF2, LKF3 and LKF4 of wackstone which have scattered larger foraminifera and high percentage of matrix. The fossil assemblages and the litholofacies of the limestone indicate the depositional environment of the limestone unit was a fore-reef shelf.

\section{COMPARISON WITH SOME SELECTED LIMESTONE UNIT FROM BORNEO AND INDONESIA REGION}

The Cenozoic limestone was widespread in Southeast Asia region. We try to compare the fauna assemblage and environment of depositional setting of the Kalumpang Formation and the limestone units at surrounding area.

The age of the Gomantong limestone has been studied by McMonagle et al. (2011) and classified the limestone at Sukau area into two different unit based on larger benthic 


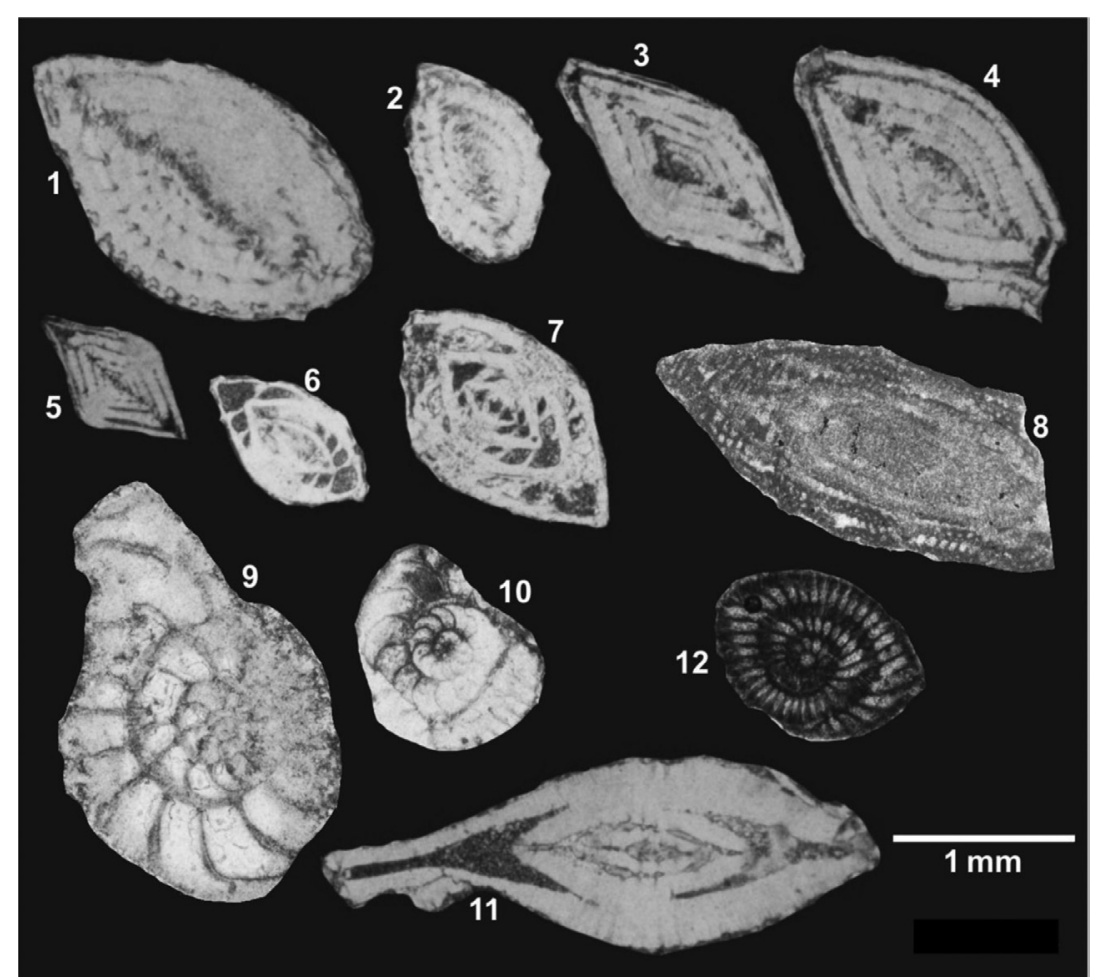

FIGURE 5. 1-2. Amphistegina bowdenensis Bermudez, equatorial-oblique section; 3-5. Amphistegina bowdenensis Bermudez, vertical section; 6-7. Amphistegina sp. vertical section; 8. Flosculinella bontangensis (Rutten) half equatorial section; 9-10. Operculina complanata (Defrance), equatorial section; 11. Operculina complanata (Defrance), vertical section; 12. Operculina sp. equatorial section

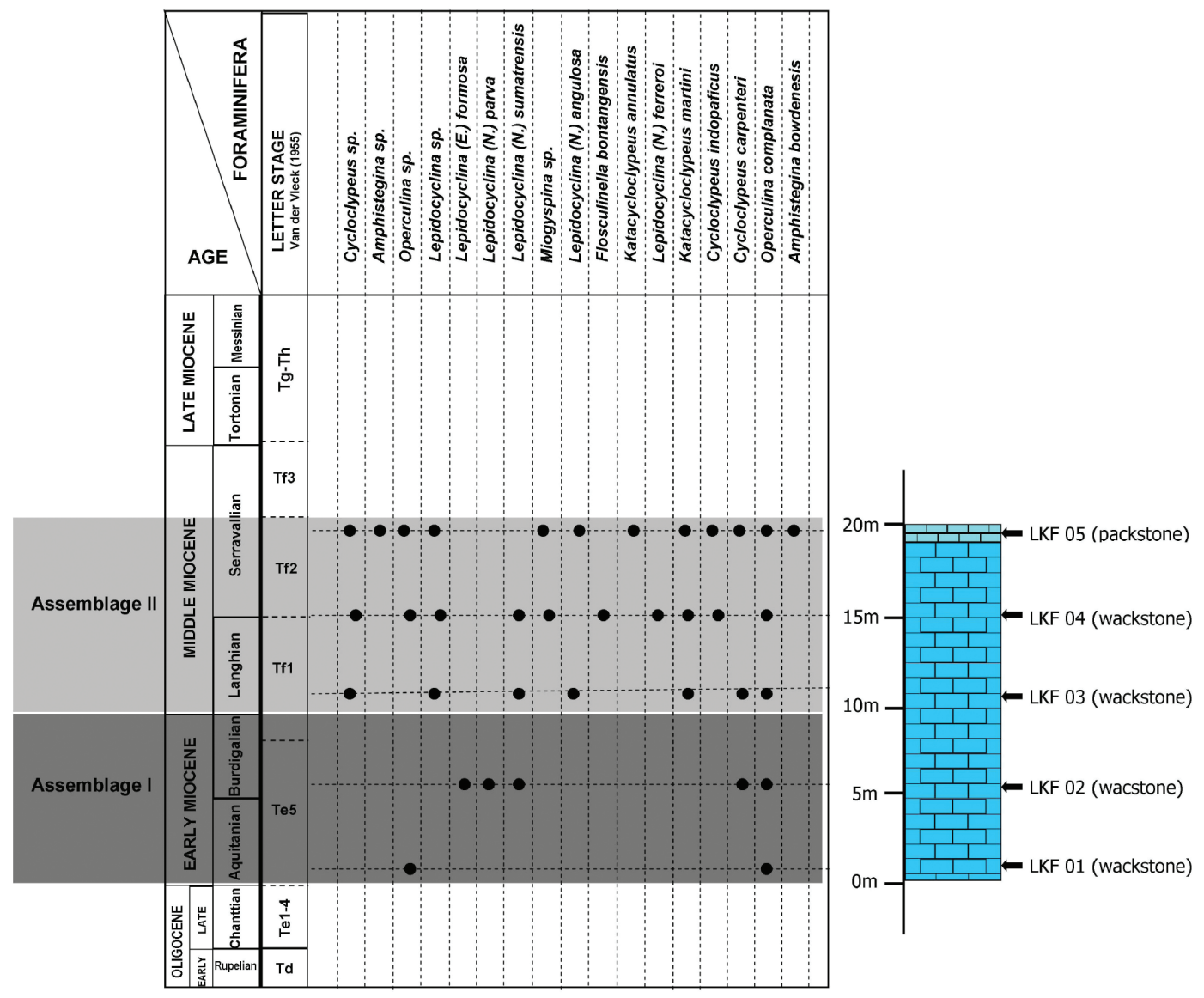

FIGURE 6. Stratigraphic distribution of larger benthic foraminiferal taxa in the limestone samples 


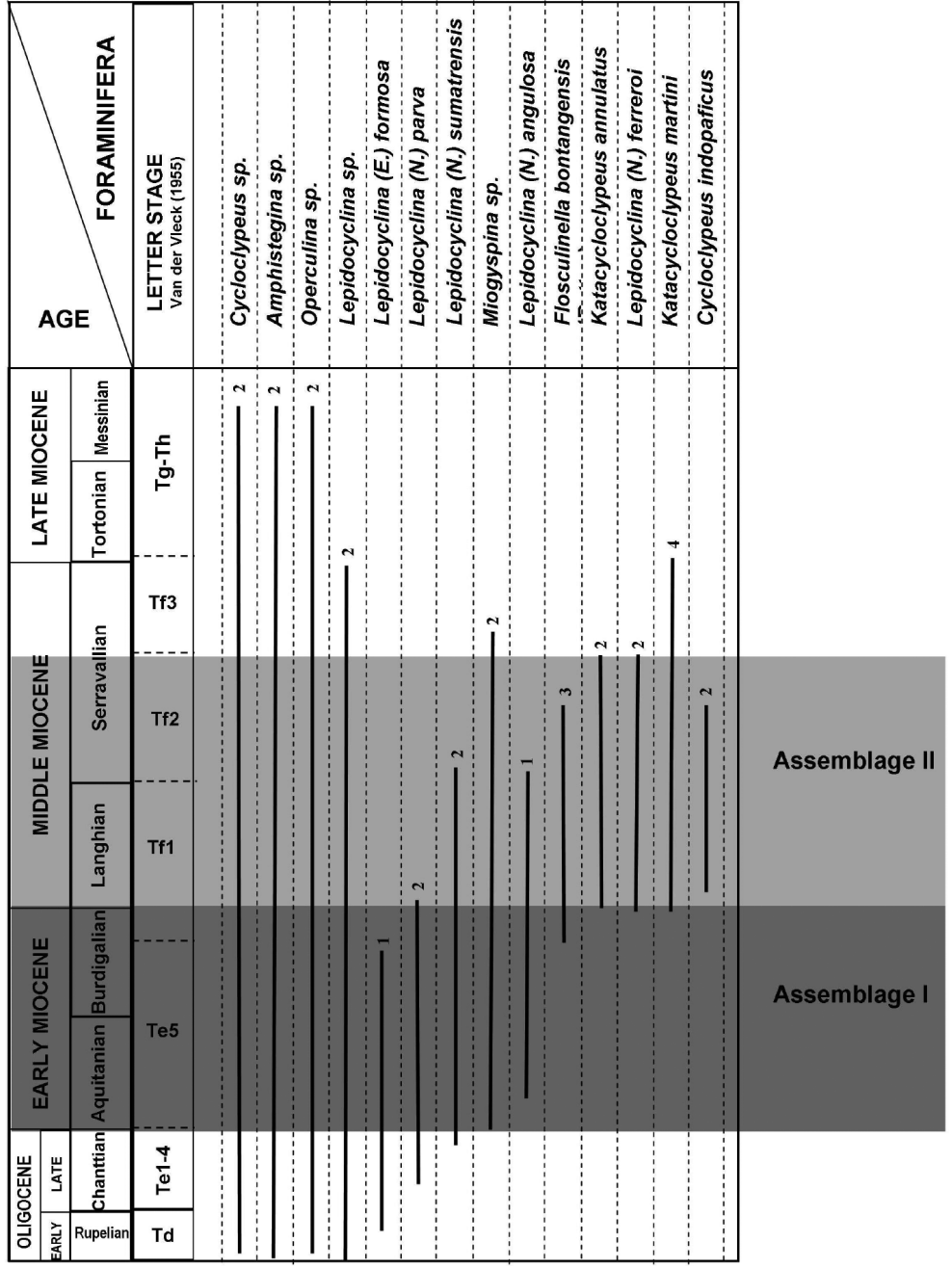

FIGURE 7. Stratigraphic distribution of selected species from previous studies; 1. Ellis and Messina (1965); 2. Adam (1970); 3. BouDagher-Fadel (2008); and 4. Cole (1963)

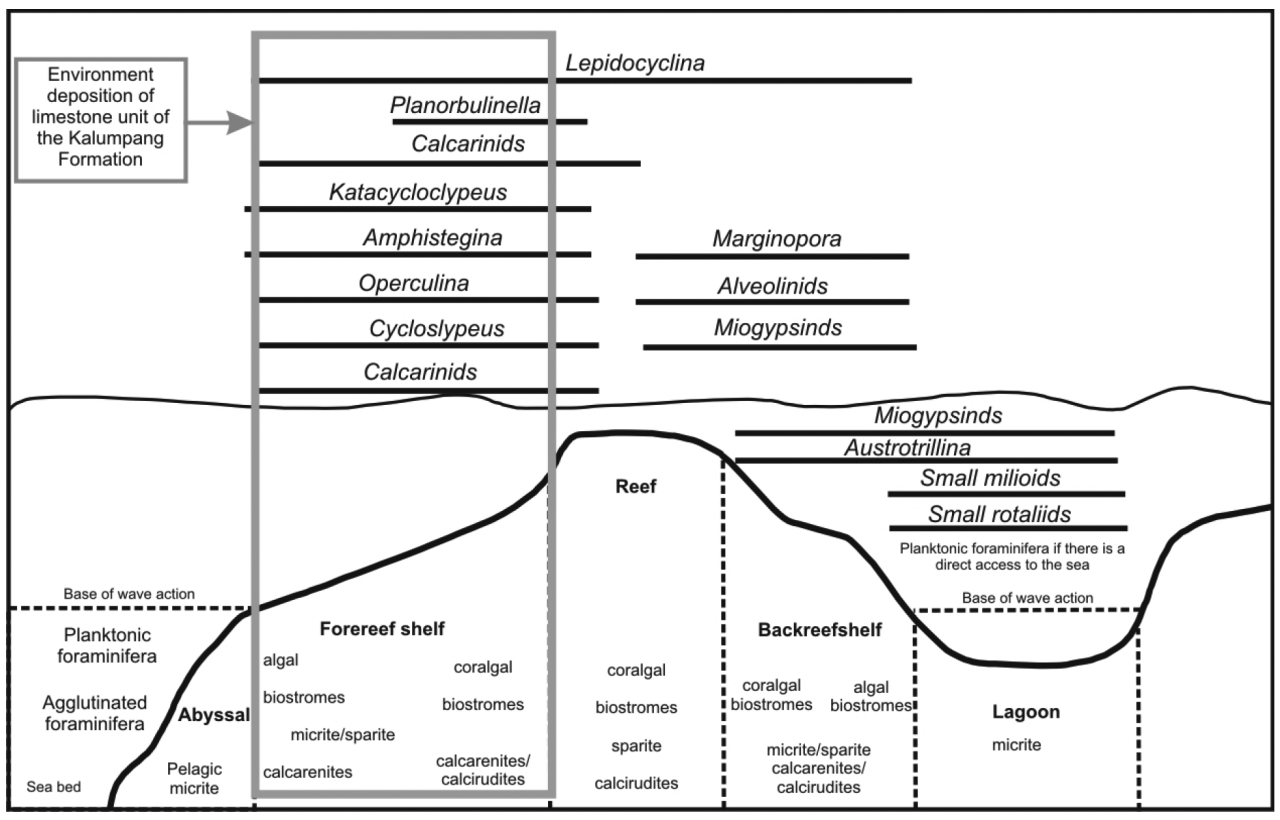

FIGURE 8. Depositional environment model of the limestone unit from the Kalumpang Formation (after BouDagher-Fadel, 2008) 
foraminifera, nanofossil and strontium isotop dating. The muddy carbonate unit was dated into Early to Late Oligocene and the Limestone unit of Gomantong Hill was date into Early Miocene. The Early Miocene of Gomantong Limestone was equivalent to lower unit or Assemblage I of limestone from the Kalumpang Formation. Larger benthic foraminifera assemblage from the Gomantong Limestone comprises Miogypsinoides, Miogypsina, Heterostegina borneensis, Neorotalia mecatepecensis, Lepidocyclina (Eulepidina) sp. Lepidocycclina (N.). ferreroi, Lepidocyclina crucifera and Lepidocyclina radiata. This assemblage indicates Early Miocene in age or equivalent to Te5. Noad (2001) has studied the Gomantong Limestone from Sukau, Sabah. Environment of deposition of Gomantong limestone was a shallow marine at an open shelf, adjacent to a coastline formed of uplifted Labang Formation. The Labang Formation consists of deep marine sediment. The Gomantong Limestone deposited in variety of depositional environments and receiving reworked clasts from the Labang Formation. Coralline algal facies passed seaward into flats with patch reefs. Down-foreslope contains of massive corals and occasional grainstone shoals gave way into branching corals and interbedded with rudstones. A sheet-like corals and giant benthic foraminiferal packstones were deposited towards the base of the slope. In the Kalumpang Formation the downforeslope and deep marine environment are not present in the outcrop section. This indicates that the Kalumpang Formation carbonate was deposited in a proximal part of the shelf far from the slope.

BouDagher-Fadel and Wilson (2000) have studied the some larger benthic foraminifera from the Batu Putih limestone at Kalimantan, Indonesia. The larger benthic foraminifera assemblage consist of Lepidocyclina $(N$.) sumatrensis, Lepidocyclina (N.) angulosa, Lepidocyclina (N.) ferreroi Lepidocyclina sp., Miogypsina sp., Katacycloclypeus annulatus, Katacyloclypeus martini, Cycloclypeus carpenteri, Cycloclypeus indopacificus, Cycloclypeus sp. and Amphistegina sp. These spesies were also found in the limestone of Kalumpang Formation. This assemblage has been reported ranging from Burdigalian to Serravallian or equivalent to Tf1 to Tf 2 . This assemblage has equivalent in age with Assemblage II of Kalumpang Formation limestone which indicates Langhian to Serravallian in age (Middle Miocene). The limestone of the Batu Putih is dominated by corals and larger benthic foraminifera are common in the basal and the upper parts of the limestone succession. The limestone was interpreted deposited in shallow water less than $20 \mathrm{~m}$ deep, as a patch reef on the delta front mouth bar with some influx of fine clastic material from the delta.

Middle Miocene carbonate has also been reported from the Gunung Sewu Limestone, South Central Java, Indonesia (BouDagher-Fadel \& Lokier 2005). The limestone consists of packstone, grainstone and rudstone dominated by coralline algae and larger benthic foraminifera. The limestone was considered as a platform carbonate deposited in warm and very shallow marine (Lokier 2000). Thirteen larger benthic foraminifera species have been identified and classified into two assemblages. The species are Austrotrillina asmariensis, Austrotrillina howchini, Katacycloclypeus annulatus, Katacycloclypeus martini, Lepidocyclina (N.) oneatensis, Miogypsina kotoi, Lepidocyclina stratifera, Lepidocyclina (N.) rutteni quadrata, Lepidocyclina (N.) sumatrensis, Lepidocyclina (Nephrolepidina) parva, Lepidocyclina delicate, Lepidocyclina stillafera, Cycloclypeus sp. and Amphistegina sp. The assemblages are indicative of Tf1 to Tf2 or equivalent to Langhian to Serravallian in age. The assemblage is also similar to Assemblage II of the Kalumpang Formation except for the absence of genus Austrotrillina, Lepidocyclina (N.) oneatensis, Miogypsina kotoi, Lepidocyclina stratifera, and Lepidocyclina (N.) rutteni quadrata.

Tacipi Formation in Sulawesi, Indonesia was deposited during Middle Miocene to Early Pliocene. The formation was deposited in large shallow marine carbonate platform with some deeper water sediment at the north. The lithology of this formation was dominated by coral, coralline algae, molluscs, benthic foraminifera and planktic foraminifera (dominated at the north). BouDagher-Fadel (2002) recorded three assemblages of larger benthic foraminifera. The lower part of the Tacipi Formation was characterized by Mid-Miocene assemblage consisting of Katacycloclypeus annulatus, Katacycloclypeus martini, Lepidocyclina (N.) oneatensis, Lepidocyclina (N.) sondaica, Planorbulinella solida and Cycloclypeus sp., Katacycloclypeus annulatus and Katacycloclypeus martini. The species were common throughout Langhian to Serravallian (Middle Miocene). The assemblage is partly equivalent to Assemblage II of the Kalumpang Formation. Other two assemblages of the Tacipi Formation are younger (Late Miocene to Pliocene) than limestone from the Kalumpang Formation.

The larger benthic foraminiferal assemblages from the Kalumpang Formation were deposited during Burdigalian to Serravallian (Late Early Miocene to Middle Miocene). The same assemblage can also be found and widespread at Southeast Asia region. The development of carbonate sediment during Miocene was probably related to fluctuation of sea-level caused by tectonic events.

\section{CONCLUSION}

The limestone unit from the Teck Guan Quarry is a part of Sipit Limestone Member in the Kalumpang Formation. The limestone is classified as wackstone and packstone. The larger benthic foraminifera indicate the age of the limestone unit ranges from Aquitanian to Serravallian (Early Miocene to Middle Miocene). Based on larger benthic foraminiferal assemblage, two assemblages have been identified namely Assemblage I ranges from Aquitanian to Burdigalian and Assembalge II ranges from Langhian to Serravallian. The depositional environment was a warm tropical shallowmarine at the fore-reef shelf zone. 


\section{ACKNOWLEDGEMENTS}

The first author would like to thank to Prof. Dr. Baba Musta for his assistance in fieldwork. We thank Mr. Sanin Awang for his assistance in preparation of thin section.

\section{REFERENCES}

Adams, C.G. 1970. A reconsideration of the Indian Letter classification of the tertiary. Bulletin of the British Museum (Natural History) Geology 19: 85-137.

BouDagher-Fadel, M.K. 2008, Evolution and Geological Significance of Larger Benthic Foraminifera. Amsterdam: Elsevier.

BouDagher-Fadel, M.K. 2002. The relationships between planktonic and larger benthic foraminifera, Middle Miocene to Lower Pliocene facies of Sulawesi. Micropaleontology 48: 153-176.

BouDagher-Fadel, M.K. \& Lokier, S.W. 2005. Significant Miocene larger foraminifera from South Central Java. Revue de Paléobiologie, Genève 24(1): 291-309.

BouDagher-Fadel, M.K. \& Wilson, M. 2000. A revision of some larger Foraminifera of the Miocene of South-East Kalimantan. Micropaleontogy 46: 153-165.

Cole, W.S. 1963. Tertiary larger foraminifera from Guam. U.S. Geological Survey Professional Paper 403E. p. 28.

Cole, W.S. 1957. Larger Foraminifera. U.S. Geological Survey Professional Paper, 280-I, pt. 3. pp. 321-360.

Dunham, R.J. 1962. Classification of carbonate rocks according to depositional texture. In Classification of Carbonate Rocks: A symposium.pp. 108-121.

Ellis, B.A. \& Messina, A.R. 1965. Catalogue of Index Foraminifera. Special Publication, 1, Lepidocyclinids and Miogypsinids. The American Museum of Natural History.

Hutchison, C.S. 2005. Geology of North-West Borneo (Sarawak, Brunei and Sabah). Amsterdam: Elsevier.

Junaidi Asis \& Basir Jasin 2013. Aptian to Turonian Radiolarians from Chert block in the Kuamut Melange, Sabah, Malaysia. Sains Malaysiana 42(5): 561-570.

Junaidi Asis \& Basir Jasin 2012. Aptian to Turonian Radiolaria from the Darvel Bay Ophiolite Complex, Kunak, Sabah. Bulletin Geological Society of Malaysia 58: 89-96.

Junaidi Asis \& Basir Jasin 2010. Radiolaria kapur dalam Kompleks Ofiolit Teluk Darvel di Sungai Sipit Lahundai, Kunak, Sabah. Borneo Science Journal 27: 1-14.

Kirk, H.J.C. 1962. The geology and mineral resources of Semporna Peninsular, North Borneo. British Borneo Geology Survey Memoir. p. 14

Lee, C.P., Leman, M.S., Hassan, K., Md. Nasib, B . \& Karim, R. 2004. Stratigraphic Lexicon of Malaysia. Kuala Lumpur: Geology Society of Malaysia.
Lee, D.T.C. 1988. Gunong Pock Area, Sempoma Peninsula, Sabah, Malaysia, Geological Survey of Malaysia Borneo Region, Report 9.

Leong, K.M. 1977. New age from radiolarian cherts of the ChertSpilite Fomation, Sabah. Bulletin Geology Society Malaysia 8: 109-111.

Lim, P.S. 1981. Wullersdorf Area, Sabah, Malaysia. Geological Survey of Malaysia, Report 15.

Lokier, S.W. 2000. The Miocene Wonosari Formation, Java, Indonesia: Volcaniclastic Influences on Carbonate Platform Development. PhD Thesis. Royal Holloway, University of London (Unpublished).

McMonagle, L.B., Lunt, P., Wilson, M.E.J., Johnson, K.G., Manning, C. \& Young, J. 2011. A re-assessment of age dating of fossiliferous limestones in eastern Sabah, Borneo: Implications for understanding the origins of the IndoPacific marine biodiversity hotspot. Palaeogeography, Palaeoclimatology, Palaeoecology 305: 28-42.

Noad, J.J. 2001. The Gomantong Limestone of eastern Borneo: A sedimentological comparison with the near-contemporaneous Luconia Province. Palaeogeography, Palaeoclimatology, Palaeoecology 175: 273-302.

Sharaf, E.F., BouDagher-Fadel, M.K., (Toni) Simo, J.A. \& Carroll, A.R. 2005. Biostratigraphy and strontium isotope dating of Oligocene-Miocene strata, East Java, Indonesia. Stratigraphy 2(3): 1-19.

van der Vlerk, I.M. \& Frederik Umbgrove, J.H. 1927. Tertiaire gidsforaminiferen van Ned.Oost-Indie. Wetenschappelijke Mededelingen Dienst van den Mijnbouw in NederlandschIndië 6: 1-31.

Junaidi Asis*

Geology Programme, Faculty of Science and Natural Resources

Universiti Malaysia Sabah, Jalan UMS

88400 Kota Kinabalu, Sabah

Malaysia

Basir Jasin

No. 22 Jalan 2/4F, Section 2

43650 Bandar Baru Bangi, Selangor Darul Ehsan

Malaysia

*Corresponding author; email: junaidiasis@gmail.com

Received: 6 December 2013

Accepted: 12 August 2015 